University of Nebraska - Lincoln

DigitalCommons@University of Nebraska - Lincoln

$1-2011$

\title{
Finding the Right Metaphor: Restructuring, Realigning, and Repackaging Today's Research Libraries
}

Joan Giesecke

Universityof Nebraska-Lincoln, jgiesecke1@unl.edu

Follow this and additional works at: https://digitalcommons.unl.edu/libraryscience

Part of the Library and Information Science Commons

Giesecke, Joan, "Finding the Right Metaphor: Restructuring, Realigning, and Repackaging Today's Research Libraries" (2011). Faculty Publications, UNL Libraries. 253.

https://digitalcommons.unl.edu/libraryscience/253

This Article is brought to you for free and open access by the Libraries at University of Nebraska-Lincoln at DigitalCommons@University of Nebraska - Lincoln. It has been accepted for inclusion in Faculty Publications, UNL Libraries by an authorized administrator of DigitalCommons@University of Nebraska - Lincoln. 


\title{
Finding the Right Metaphor: Restructuring, Realigning, and Repackaging Today's Research Libraries
}

\author{
Joan Giesecke \\ University of Nebraska-Lincoln \\ Lincoln, NE, USA
}

\begin{abstract}
To change from collection-centric to user-centered research libraries and to survive in tough economic times, libraries face 2 major challenges: 1st, libraries need to change how they are viewed by their constituencies so they are seen as indispensable; and 2nd, libraries need to help the librarians and staff change their own mental models of their roles to remain relevant in these changing times. Metaphors are one way to help people connect terms in new ways so they develop new images of those terms. For more than 100 years, libraries have used metaphors to seek connections that will help people see libraries as something other than warehouses for books. This article will explore various metaphors being used in the library field and how these metaphors can help libraries introduce change to improve their chances of receiving the support needed to survive.
\end{abstract}

Keywords: metaphors, research libraries

Transitions. Change. Repackaging. Survival. These themes dominate our field as libraries seek to reinvent themselves in a 2.0 world to stay relevant in the competitive information environment. Libraries face two major challenges in implementing change in today's world. First, libraries need to change how they are viewed by their constituencies so they are seen as indispensable. Second, and equally challenging, libraries need to help librarians and staff change their own metal models of their roles to remain relevant in these turbulent times. Metaphors are one way to help people connect terms in new ways so they develop new images of those ideas. 
What are metaphors or why is hail always the size of something else? Metaphors, as we all know, are phrases that connect unlike items that actually have something in common or phrases where one thing is used to designate another (Dictionary.com, 2010). Metaphors such as Shakespeare's "All the world's a stage, and all the men and women merely players," presents us with a different image of reality (Shakespeare, n.d.). As another example, Keith Fiels, executive director of the American Library Association (ALA), at the division leaders/BARC Midwinter meeting at the ALA meeting, January 2009, was describing the purpose of an initiative fund used for projects that relate to the ALA Strategic Plan. He noted that the fund helped ALA be more nimble, and then noted that this made ALA a nimble dinosaur. These metaphors are very useful examples of how metaphors help create images for people to see things differently. Metaphors can help us accept new ideas and to expand our views.

What does this have to do with the size of hail? Hail helps explain why metaphors work. There is an established chart for how to describe the size of hail. From the government National Oceanic and Atmospheric Administration (NOAA) Web site (2010) you learn that pea-size hail is one-quarter of an inch whereas golf ball-size hail is one and three-quarters of an inch. Scientists learned that people were more accurate in reporting the size of hail when they compared the hail to a known object than when they tried to guess the size in inches. The comparison approach provides an understandable standard way for people to describe an event.

\section{Estimating Hail Size}

- Pea $=1 / 4$ inch diameter

- Marble/mothball = 1/2 inch diameter

- Dime/Penny = 3/4 inch diameter - hail penny size or larger is considered severe

- Nickel $=7 / 8$ inch

- Quarter = 1 inch

- Ping-Pong Ball = 1 1/2 inch

- Golf Ball = $13 / 4$ inches

- Tennis Ball = 21/2 inches

- Baseball = $23 / 4$ inches

- Tea cup $=3$ inches

- Grapefruit = 4 inches

- Softball $=41 / 2$ inches

Metaphors have the same power. They help people think differently about an event or activity. They help us change or confirm our mental models. Because metaphors reflect conceptual or mental models, metaphors can be used to identify how someone perceives a particular institution, situation, idea, or how they 
look at things. Metaphors can provoke powerful images that can persuade others of a particular solution or point of view. They can frame a problem in a way that sets the direction for what solutions might be considered, but they do not result in canned solutions. For example, if the information highway metaphor for networked information conveys the idea that all information is available for free on the highway, then the need to support libraries as a source for information becomes questionable.

Librarians have been using metaphors to describe libraries and librarians since the modern library movement began in the late 19th century. These early leaders, such as Melville Dewey, used various images to "locate desirable meanings in other walks of life and associate them with their renewed but misunderstood institutions" (Nardini, 2001). ${ }^{1}$ Library leaders in the late 1800s sought to redefine libraries in terms of education and schools. Others looked to religious metaphors to describe the importance of libraries to the local community. They sought to overcome the negative terms often used to describe libraries and librarians. Even in the 19th century, libraries were described as "just warehouses for books" or as "antiquarian museums" (Larner, 1998). Libraries were viewed as dusty collections of print material that were guarded by librarians and not meant to be used. This dismal image is a true contrast to the libraries of ancient Greece and Rome where the scholars who oversaw the private libraries were seen as important members of the community. In Rome, a librarian was a "stepping stone for the ambitious government servant" (Krasner-Khait, 2001).

Our library leaders of the 19th century tried a number of more positive metaphors to describe the profession. They argued that a community library was the people's university. In the academic world, the library was viewed as the laboratory for the humanities. Some leaders described branch libraries as the parish churches of literature and education. Each of these metaphors centers the library with a positive educational or community value.

The beginning of the 20th century saw libraries align themselves with business metaphors, emphasizing efficiency and incorporating business principles into the organization. Libraries also equated themselves with public utilities as institutions deserving public support. Libraries turned to department stores to describe the type of customer service that was needed to help library employees understand the service ethic that was becoming more important.

Not much had changed by the last decade of the 20th century. Danuta Nitecki, in a study of the use of metaphors by faculty, administrators, and libraries to describe academic libraries as reported in the Chronicle of Higher Education opinion pages, found that the following metaphors were used:

- library as storehouse,

- electronic access,

- activist, 
- partners,

- location,

- measure of academic quality,

- object of ownership and

- economic setting. (Nitecki, 1993, p. 262)

Administrators were likely to describe libraries as partners with the campus, while faculty members were more likely to view libraries as repositories for physical information. Librarians attributed an activist role to libraries, yet also saw the library as a storehouse for information. These different perspectives help remind us that the impact of a particular metaphor is influenced by the background and positions of the senders and receivers of the messages as well as by the message itself. Nitecki also noted that additional metaphors found in the literature include library as salon, as a smorgasbord where specialists may diversify their diets, and a window on local events, as a watch tower, and as a multimedia kiosk (Nitecki, 1993, p. 260).

All of these concepts are very familiar to us. We are still seeking the right way to describe the library as more than a warehouse or museum for books. We bring in customer service training and turn to places such as the Disney Corporation to try to help librarians understand how to connect to their constituencies. We talk about our place on the information highway, the well-known metaphor for the Internet. We seek ways to be seen as flexible and agile.

\section{Librarians}

Metaphors have also been used to help recruit new librarians to the field. In Dewey's time, library leaders equated librarians with teachers and educators to bring more prestige to the profession. In the beginning of the 20th century, librarians referred to themselves as businesspeople promoting efficient operations and developing sound operating principles. These leaders hoped that equating libraries with educational institutions and business enterprises would help attract teachers and businessmen or department store employees to the library field.

By the end of the 20th century, the library field had incorporated numerous terms from the computer industry to describe librarians. Librarians were now information engineers, information professionals, and information specialists or information navigators on the information highway. We even referred to ourselves as the new search engines or as middleware. How odd that we equate ourselves to computer programs to raise our status among our constituencies. Research libraries could be described as part of the knowledge management system, participating in the dissemination and use of knowledge. Each of these images is an effort to improve the visibility of librarians and to change the way people think about and describe librarians. The images are also ef- 
forts to encourage librarians to change and adapt to the complex, information environment.

School librarians have used a number of terms to describe school positions from librarians to media specialists to learning specialists. Today, in the Lincoln Public Schools in Nebraska, the media specialists are also termed teacherlibrarians and many are managing both the library and the computer laboratories. Again, librarians are seeking terms and metaphors that indicate librarians are professionals who do more than read and shelve books.

In the 21st century, academic library leaders have sought new metaphors to describe the changes needed in the workforce so libraries can take on new roles. Jim Neal (2006) referred to the "feral professionals" who hold professional positions in our libraries but do not necessarily have a master's degree in library science. These professionals include positions in human resources, development, special collections, and digital initiatives, to name just a few areas. The Council on Library and Information Resources (CLIR) used the term "hybrid librarians" to describe the post-doctoral fellowship program that brings PhD trained professionals into library positions to bridge the gap between the libraries and the teaching departments (Walter, 2008). CLIR fellows have been involved in a variety of projects often centering on new teaching models, digital scholarship, and special collections efforts.

Steven Bell and Jim Shank used the term blended librarians to describe the need for librarians to become more integrated in the teaching process by developing skills in instructional technology and instructional design ("Blended librarian," 2005). Blended librarians become partners with faculty and other academic professionals in designing courses and incorporating information literacy and research skills into academic programs to achieve student learning outcomes. Blended librarians therefore become part of the instructional development team (Bell \& Shank, 2007). Blended librarians may be seen as a new metaphor for the librarian-educator metaphor that Dewey used.

John Budd (2009), University of Missouri School of Library Science, writes about the need for academic liaison librarians to be embedded librarians, closely tied to the academic departments they serve. Embedded librarians may have office hours in the academic department or even a joint appointment in an academic unit. This image expands the approach that branch librarians located in branches within academic buildings have taken to liaison librarians in a main or centralized library. Having the librarians physically closer to the faculty can increase informal communication and hallway conversations to keep the librarian well informed about and sharing information with the academic department.

In a recent article in American Libraries, Steven Bell (2009) suggested that we needed to move from the metaphor of gatekeeper to the metaphor of gate openers to describe our future. He argues that we need to shift from "a focus on creating access to resources to creating meaningful relationship with community 
members." We need to invite people into our libraries and to engage with them in their research. By creating great library user experiences we will create strong relationships with our users that can help generate support for our institutions. By creating meaning for users and developing relationships, librarians become an essential part of the community.

\section{Library Metaphors}

Library as a Body Part

We are all familiar with the concept of the library as the heart of the university, a phrase attributed to Charles Eliot, President of Harvard in the 1860s. ${ }^{1}$ At Yale University, that phrase was carved above the entrance of the Sterling Memorial Library, which opened in 1930. But certainly we are also aware of the conversations that the library may be losing its place as the heart and soul of the university. Perhaps those who argue that the World Wide Web had replaced librarians would suggest that the library as the heart of the university is a heart with clogged arteries and in need of bypass surgery. Can we describe libraries as healthy hearts? Will some other body part be a better metaphor for today's research library?

Lorcan Dempsey (2008) of OCLC in his Weblog posed a similar question on May 13, 2008. Is the library the brain, the blood, or the lungs (Dempsey, 2008)? One posting suggests the library is the foot on which the institution rests. The comments on Dempsey's blog entry did not yield a consensus. Edward Shepard, head of collection development at State University of New York, Binghamton, mused about the same question in a report on the October, 2008 Readex Digital Institute (Shepard, 2009). He wondered if the library is more of a muscle pumping information throughout the institution. Perhaps the library is the circulation system uniting the parts of the university. He concluded that the library should be seen as an active muscle to remain effective. While being the heart of the university may be comforting to some, it does not seem to be a metaphor that helps others see the library as an active part of the campus.

\section{Library as Conversation}

Another set of metaphors describes the library as the connector between content and the user of the content. Along these lines, J. Z. Nitecki (1993, p. 260) describes librarianship as a communication process involving information content and concepts, the ways that information is relayed, and the recipients of the content. R. David Lankes, Joanne Silverstein, and Scott Nicholson (2007) describe libraries as part of the conversation business, arguing that knowledge is created through conversation. They describe conversation theory, which is a means of explaining cognition and how people learn. People connect ideas and learn through 
conversations with others and as internal conversations between themselves and the written text. Librarians facilitate conversations or learning through information literacy activities, teaching critical thinking skills, and by preserving the social record so people can connect with history. Further, in today's technology environment, libraries become part of the participatory network or social networks that bring people and content together in ways that allow users to create their own connections. We have finally created the shared minds that Michael Schrage (1995), research associate at Massachusetts Institute of Technology's Sloan School of Management, described in Shared Minds: The New Technologies for Collaboration. He wrote about how libraries can bring people together through technology. Now, libraries join Facebook and Twitter, to engage our constituencies in our world.

\section{Library as Place}

As the need for libraries as physical spaces has come under discussion, the library field has created numerous metaphors to help people imagine the library as something other than a quiet place with dusty books and an unwelcoming environment. Some have equated libraries with bookstores and coffee houses. These are places where people can gather, access electronic information, interact with colleagues without being told to be quiet, and still enjoy a cup of coffee and a snack. Library as Starbucks or library as Barnes \& Noble comes to mind. A recent posting on the School Library Journal blog contrasted the idea of library as grocery store and library as kitchen (Valenza, 2008). Library as grocery store is an image of libraries as places where one gets stuff whereas library as kitchen invokes the image of a place where people do things together. Kitchens are seen as social spaces, gathering spaces, and comfortable spaces where family and friends interact. This is the image many of us are trying to create for our libraries.

Other places are also used to describe libraries. As previously noted, the humanities disciplines describe the library as their laboratory. This metaphor is often tied to the need for some type of start up funds for new humanities faculty just as universities put together start up packages for lab scientists. For students we describe the library as their academic living room or place where they can gather and study. Recently our library at University of Nebraska-Lincoln (UNL) was rated by students as one of the best places on campus to grab a quick nap between classes. At least they see the place as safe and welcoming. We are beginning to describe our comfortable seating areas as the mini-bed and breakfast for the campus as students relax in a comfortable chair, get out their laptops, put down their cup of coffee or soda and fall asleep. Again, the challenge is to help students view today's academic libraries as a welcoming place for them and not as a large warehouse for books. As already noted, the metaphor of library as a warehouse or a museum for books has been with us for more than 
120 years and is still one that we have not been able to eliminate from the conversations about libraries.

Digital, "e," and 2.0

There are an amazing number of metaphors describing libraries in terms of digital work, electronic resources, and 2.0 anything. We have library 2.0, librarian 2.0, as well as the coming 3.0 versions of these terms. We have digital libraries, digital collections, and digital librarians. We put the letter " $\mathrm{e}$ " in front of any format. We even have digital microfilm which again may be an effort to connect an understanding of one format with another format. In each case, these metaphors are being used to help librarians understand the need to change and to incorporate the social networking and technology of our users into our libraries. The terms are also an effort to help users see the library as technologically relevant in a world of Google and Amazon.com. Some research libraries, such as UNL, are now digital publishing services, creating institutional repositories and hosting open access journals. We still need a metaphor for the changing role of the library as publisher as well as the library as a collector of information.

\section{Ecology}

One set of metaphors that seems particularly helpful to today's research libraries is to think of the library as an ecosystem that promotes biodiversity. Scott Walter (2008), in an article in Library Journal, noted that libraries encompass "multiple species" including our users, traditionally trained librarians, and a variety of professionals from other fields, and the interactions and relationships among these different groups. In this ecosystem, mutualism and coevolution are key to the survival of the library rather than competition and survival of the fittest. In the ecosystem species will survive who provide mutual benefit to each other. Mutualism does not try to change each specie but rather emphasizes the strengths and benefits that each specie brings to the system. In the same way, in research libraries, each profession brings strengths to the system to help the system thrive and survive.

The metaphor also emphasizes the importance of building relationships and sees the library system as a set of relationships. It changes the library from a collection-centric institution to one that is user-centered. It can help library leaders think in terms of building partnerships on campus, continuing to build relationships among research libraries, and bringing together the variety of skills (or species) that are needed today to provide the services and collections that are essential to our survival. For example, at the 2003 Conference of the International Association of Aquatic and Marine Science Libraries and Information Centers, Peter Fritzler from the University of North Carolina at Wilmington used the met- 
aphor of coral reefs to describe libraries. Coral reefs, according to Fritzler (2003), are the rainforests of the sea, a very diverse, productive, and ever-changing environment. Fritzler used this image to capture the attention of the faculty and students at the university's Center for Marine Sciences (CMS). The image helps to describe the set of education and reference services that the libraries could provide to their remote CMS by establishing a symbiotic relationship between the CMS and the library.

Further, the ecosystem and biodiversity metaphors include the concept that each library needs to relate to its local environment. The library cannot just adapt ideas from other fields and implement them in an automatic way. Rather library leaders need to assess options and bring those ideas to their environment that will be mutually beneficial to their own ecosystem. The ecosystem metaphor of positive relationship building and interaction can be integrated with positive organizational psychology, learning organization theory, and strengths-based leadership to help libraries thrive in these difficult financial times.

Finally, the ecosystem metaphor can help libraries incorporate new roles and services that are mutually beneficial to the system. Increasing the visibility of and access to special collections materials is a strength libraries can pursue that will increase the diversity of resources available to researchers. Libraries creating robust institutional repositories and digital publishing units contribute to the overall ecosystem. Having students create digital content and products for use by others in the system builds a new cohort of researchers who can begin to see the library as more than a collection of books. With so many options available to librarians for how to change, the ecosystem metaphor can help leaders prioritize choices by thinking about the unique strengths of the library and how to best integrate those strengths in an environment of mutual benefit and increased biodiversity.

\section{Metaphors at UNL Libraries}

At UNL, we have tried any number of metaphors to help our own librarians and staff to imagine new roles, cope with change, climb outside the box, and repackage our services. We have also tried different ways to help the university administration, faculty and students view the library as a vital, relevant part of the scholarly enterprise. Librarians at UNL have faculty status and tenure and have had to review and revise their view of promotion and tenure criteria as the campus has made changes in overall criteria and processes. These various reviews have allowed us to introduce different metaphors for describing the work of the librarians. A number of years ago the librarians adopted the model or metaphor of the scholar-practitioner to describe their role as faculty. The term was borrowed from the College of Education and Human Sciences and nicely describes the need for librarians to be active researchers staying current in the field, while 
providing good practice. The term also emphasizes that research informs practice so that the libraries can respond to the changing environment. The model has also made it possible for the library faculty to define themselves in broad enough terms that the library faculty includes members with $\mathrm{PhD}$ degrees but no MLS degree. It has allowed the faculty to add those involved in digital humanities research, digital initiatives, and electronic publishing to the library faculty on equal terms.

For the library, we have tried a number of different metaphors to describe our changing services. For students we have used the term academic living room, a metaphor that has been picked up by our admissions office and is used in student recruiting efforts to describe a space for students to study and to gather with colleagues. We have tried a number of terms to describe the addition of digital media services to the libraries. We tried digital learning librarians to describe those involved in digital media services who were hired to help faculty incorporate digital resources into their course assignments. We renamed the microforms area the media services area and moved the digital media computers from the computer area to the microforms room. We are still seeking a better way to describe the unit that helps students edit video and audio files, circulates cameras and video recording equipment, and now "houses" digital microfilm. As previously noted, we seem to run a bed and breakfast for some students, a social gathering place for others, and a snack and study zone for others. In each case we are seeking a way to relate our work to our constituencies in terms that will resonant with them.

We have emphasized library as partner to describe ways that we assist departments in electronic publishing efforts. For a number of years we have worked with other units on campus to create image databases using the ContentDM software. We learned early on that our art history faculty were not inclined to use published image databases but preferred their own slides. We partnered with the department on an internal teaching grant to develop a pilot set of digitized slides from the art history slide collection and to modify the equipment in their large teaching classroom to allow true full-sized dualimage projection of slides from a single computer station. The demonstration project was successful in part because of the partnership approach. The libraries were able to build on this demonstration project and partnered with museums on campus to add digital images of their collections to our database at no cost to the museums. Some groups that work with us do have resources to contribute to the project. For these groups we provide whatever level of support they need. For example, Nebraska Educational Television is using our software as the search engine for their database of streaming video. For this group, we showed them how to use the software and they took the project from there. They particularly like the fact that their videos can be searched through our catalog as well as through their own Web site or through Google. By customizing our approach to each group's needs, we have been able to create a variety 
of digital publishing projects. The partnership metaphor works well for us because it fits with the campus culture and signified that we were not looking for resources from others but came to the project with resources. The deans at UNL also use metaphors to describe the UNL culture. The deans will say that if you like to swim with the sharks, UNL is not the place to be a dean. The shark metaphor helps others understand our collaborative culture that encourages partnerships.

We are also trying to find a term that will better describe the search and discovery tool, Encore from Innovative Interfaces, that runs our catalog and integrates a variety of content databases into one search. We have partnered with our campus museums to add records for their specialized book collections to our catalog and to add images from their collections to our ContentDM databases. We have our institutional repository to preserve faculty and student scholarship, provide open-access journals, and publish original scholarly monographs. We have the digital humanities scholarship produced through our Center for Digital Research in the Humanities. And we have our digitized special collections. These various content types, with MARC, Dublin Core, EAD, or TEI records can all be searched through our catalog. We need a term that describes the complexity of a system that searches all these resources, includes faceted searching, and community tagging. We tried describing the catalog as central intelligence for the campus, bringing together a variety of resources, formats and publications together through one search engine, but that did not resonate with anyone. The best we have so far is to describe the catalog as "Google meets Amazon.com."

Finally then for UNL, where we are coping with financial constraints by partnering with other units on campus to remain visible and essential to the academic enterprise, we could be described as a group of scholar practitioners who manage the academic living room, are a publishing partner, and who bring a Google and Amazon.com experience to the search and discovery of scholarly resources to our students and faculty.

\section{Conclusion}

Library leaders have struggled for many years to find the right metaphor to describe the importance of libraries and librarians. No one has found the perfect metaphor that adequately describes the complexity of the research library in terms that resonant with the world outside our walls. However, the ecology metaphors can be helpful in describing for librarians, professional and technical staff the need to change and why we need new skills in our workforce to stay relevant in a changing environment. While we look for ways to stay relevant, integrate new businesses into our libraries, and a new business model for our library we will continue to seek the right metaphors to describe who we are, what we do, and why we need support. 


\section{Notes}

1. From the quote cum adage, "The Library is the Heart of the University," attributed to Charles William Eliot, President of Harvard University.

\section{References}

Bell, S. (2009) From gatekeepers to gate-openers. American Libraries 40:8/9, pp. 50-53.

Bell, S. and Shank, J. (2007) Academic librarianship by design: A blended librarian's guide to the tools and techniques American Library Association, Chicago, IL

Blended librarian - Retrieved from http://blendedlibrarian.org/overview.html

Budd, J. (2009) Academic library data from the United States: An examination of trends. Library and Information Science Research Electronic Journal 19:2, pp. 1-21. Retrieved from https://libres.curtin.edu.au/

Dictionary.com Metaphor - Retrieved from http://dictionary.reference.com/ browse/metaphor

Fritzler, P. (2003, October 5-9) Building REEAFS: Repackaging and personalizing library services to remote marine science facilities. Conference Proceedings for the International Association of Aquatic and Marine Science Libraries and Information Centers - 29th Conference, October 5-9, 2003 (pp. 41-46). Mystic, CT: IAMSLIC

Krasner-Khait, B. (2001) Survivor: The history of the library. History Magazine 4 , pp. $1-7$.

Lankes, R. D. , Silverstein, J. and Nicholson, S. (2007, December) Participatory networks: The library as conversation. Information Technologies and Libraries 26:4, pp. 17-33.

Larner, F. (1998) The story of libraries: From the invention of writing to the computer age pp. 24-26. Continuum Publishing, New York, NY

Dempsey, L. (2008, May 13) [Weblog comment]. - Retrieved from http://orweblog. oclc.org/archives/001636.html/

Nardini, R. (2001) A search for meaning: American library metaphors, 1876-1926. Library Quarterly 71 , pp. 111-140.

Neal, J. (2006) Raised by wolves: Integrating the new generation of library professionals into the academic library. Library Journal 131:3, pp. 42-44.

Nitecki, D. (1993) Conceptual models of libraries held by faculty, administrators, and librarians: An exploration of communications in the. Journal of Documentation 49:2 , pp. 260-277.

NOAA Hail ... damage to property and crops ... - Retrieved from http://www.erh. noaa.gov/cae/svrwx/hail.htm

Schrage, M. (1995) Shared minds: The new technologies for collaboration Doubleday , New York, NY

Shakespeare, W. As you like it Act 2, Scene 7, Iaggard and Blout, London, England

Shepard, E. (2009, September) Heart or muscle? The library in the digital age. Readex Newsletter - Retrieved from http://www.readex.com/readex/newsletter. cfm?newsletter $=242$

Valenza, J. (2008, August 25) Library as domestic metaphor - Retrieved from http:// www.schoollibraryjournal.com/blog/1340000334/post/90032209.html 